\title{
FEMININE WORLD OF ANN OAKLEY'S NOVELS
}

\section{Alla Marchyshyna}

\section{INTRODUCTION}

What is there in a plot? A fiction text of the so-called "traditional" structure comprises a set of elements that make up its story, i.e. a plot. Since school years, the reading audience knows that there should be such components as introduction, conflict, rising action, climax, falling action, denouement. Their arrangement may be different depending on the text composition but the given list is almost complete and is expected to provide the exciting narrative. The present study isn't aimed at challenging the relevance of constituents of the plot structure. On the contrary, it seeks to prove whether it is enough for a plot as a text skeleton. Here, the assumption is made that a plot may acquire one more characteristic feature: gender colouring.

There may be suggestions that the latter is rather a matter of stylistics than of a plot itself. The deep insight into some texts gives rise to the idea that it does refer to the plot. Text stylistics due to its nature focuses on the imagery in its general and peculiar senses: it transforms concepts into images thus provoking the readers' intellectual and emotional spheres making the process of text contents perception interesting and emphatic. Stylistics is there on the surface.

Plot is another cup of tea. It is deeply inside the author's worldview implemented into the events that constitute the plot. The selection and arrangements of events reflect the author's hierarchy of (literary) values. As far as any literary text is not a precise reflection of the world but is its artistic representation, the very choice of the events the author endows with importance and functioning in a plot determines its gender bias and identification signals. The plots with distinctive gender colouring are characteristic of Ann Oakley's novels.

A plot of a fiction text is not just a kind of storytelling, neither it is a container of events which either the author or the narrator hurry to make public to impress the reader. First, to a complete text, a reader might ask a question, "What has happened?" There is no plot if nothing has happened. And here it is the starting point to identify the gender colouring of the plot. Though some researches prove that "gender differences emerge more commonly in spoken than in typed 
narratives"1, similarly, there exists psychological assumption that importance of events (What has happened? Has anything happened?) is ranked differently by men and women: "men and women are two distinct groups of people who think, communicate, influence, and lead in different ways" . Thus, the sequence of events making up a plot is gender dependent.

Second, there arises a question how the plot events are arranged. Here, the role of an author is crucial as far as it is an agent who translates the scope of information to a narrator and endows this text construct with functions to render the assigned "data" to a reader. In this respect, R. Franzosi's observation proves successful stating that "narrators and narratees constrain how events are narrated. The focus on how involves a focus on plot (rather than story), on rhetorical efficacy, on the strategic mix of pure narrative, description, and evaluation, and on the effective use of language)"3. These verbal means of a plot expansion become semantically and stylistically loaded elements determining text perception and interpretation.

Gender-related events assessment commonly originates from a bipolar spectrum of problematic loadings on the factors both triggering and resulting from the events in question. This way the dimensions of plot lines are specified which are termed gender-role preferences ${ }^{4}$. They are implicit in gender-related social norms and the gender-related characteristics which acquire verbal forms in a fiction text. Hence, nonrelative, absolute statements are hard to maintain in a belles-lettres style which is qualified as highly subjective and biased (see, for example, M. Longo ${ }^{5}$ who considers a literary text as a result of a subjective process) whereas only "science has been traditionally seen as the major, if not the

1 Grysman A. et al. The influence of gender and gender typicality on autobiographical memory across event types and age groups. Memory \& Cognition. 2016. Vol. 44. P. 856.

2 Merchant K. How Men and Women Differ: Gender Differences in Communication Styles, Influence Tactics, and Leadership Styles. Senior Thesis. Claremont McKenna College. CMC Senior Theses. 2012. Paper 513. URL: http://scholarship.claremont.edu/cmc_theses/513. P. 13.

3 Franzosi R. Quantitative Narrative Analysis. Thousand Oaks: SAGE Publications, Inc., 2010. P. 46.

${ }^{4}$ Shapin S. The Science of Subjectivity. Social Studies of Science. 2011. Vol. 42 (2).

5 Longo M. Fiction and Social Reality. Literature and Narrative as Sociological Resources. London and New York: Routledge, 2016. P. 111. 
only, domain where objectivity lives" ${ }^{\text {. }}$. Scholars may even go too far and doubt what fragment of reality is the text focused on and to what extent it relates to reality. Take, for instance, H. M. Davidson's interpretation of M. Proust's theory of text where the similar idea is emphasized ("Proust is here sharing a common understanding of literature, namely the feeling that it contains some form of truth about reality; but it is not clear, what kind of truth this is!"7).

Likewise, it is caused by the long-rooted stereotypes. As N. Ellemers states, "gender stereotypes affect the way people attend to, interpret, and remember information about themselves and others" 8 . The same suggestion was proved by the empirical research ${ }^{9}$ which concluded that narratives depend on gender bias both in the way of factual elaboration and interpretative elaboration.

\section{Method}

To qualify the plot events as female or male dominated, McAdams' life story coding system ${ }^{10}$ may serve the ground for differentiation. Here, the two basic concepts of agency and connectedness constitute the milestones for male or female priority in events selection and description. It continues Bakan's ${ }^{11}$ theory of agency and communion where agency is meant as "personal achievement, power, and the assertion of the individual self $\langle\ldots>$ Themes of communion express desires for love,

6 Longo M. Fiction and Social Reality. Literature and Narrative as Sociological Resources. London and New York: Routledge, 2016. P. 170.

${ }^{7}$ Davidson H. M. The literary representation of reality. Res Cogitans. 2018. Vol. 13 (1). P. 115.

${ }^{8}$ Ellemers N. Gender Stereotypes. Annual Review of Psychology. 2018. Vol. 69. P. 275.

9 Grysman A. et al. The influence of gender and gender typicality on autobiographical memory across event types and age groups. Memory \& Cognition. 2016. Vol. 44. P. 856-868.

${ }^{10}$ Mansfield E. D., McAdams D. P. Generativity and themes of agency and communion in adult autobiography. Personality and Social Psychology Bulletin. 1996. Vol. 22. P. 721-731; McAdams D. P. et al. Continuity and change in the life story: A longitudinal study of autobiographical memories in emerging adulthood. Journal of Personality. 2006. Vol. 74. P. 1371-1400.

11 Bakan D. The duality of human existence. Boston: Beacon Press, 1966. $242 \mathrm{p}$. 
friendship, and community"12. The scholars consider agency as "the expression of autonomy and self-efficacy, a sense of controlling one's life" whereas connectedness "is a sense of relatedness and valuing others" ${ }^{\prime 4}$. Though agency and connectedness have acquired malestereotyped and female-stereotyped features respectively, this study aims neither to verify nor to counterclaim the traditional beliefs. The research seeks to demonstrate how gender related and gender valued events and their interpretation construct the plot of Ann Oakley's novels "The Men's Room", "Matilda's Mistake", and "A Proper Holiday".

\section{1. "The Men's Room"}

The story focuses on adultery, a love affair between the protagonists, a man and a woman. It may seem a typical situation at first sight. Two middle-aged university professors abandon their spouses in search of new passion. Deep in the family and household chores, they are thirsty for adventure and risk, open to changes and challenges. It produces a chain reaction: their refusal to stay in the marriage results in their spouses' desire to take revenge for breaking the wedding vows. Everybody gets rid of family obligations, and the problem is not resolved but deepened.

The lovers get nothing what they expected. They face moral confrontation, combat criminal sanctions for adultery, go through monetary damages, suffer from emotional distress and so on.

Charity claims herself guilty for her son's disease development caused by the nervous breakdown after the parents' divorce. This signals Charity's stereotyped apprehension of a wife's and mother's role in the family: "a wife's adultery was historically seen as proof of parental unfitness in child custody proceedings"

${ }^{12}$ McAdams D. P. et al. Continuity and change in the life story: A longitudinal study of autobiographical memories in emerging adulthood. Journal of Personality. 2006. Vol. 74. P. 1376.

13 Grysman A. et al. The influence of gender and gender typicality on autobiographical memory across event types and age groups. Memory \& Cognition. 2016. Vol. 44. P. 857.

14 Grysman A. et al. The influence of gender and gender typicality on autobiographical memory across event types and age groups. Memory \& Cognition. 2016. Vol. 44. P. 857.

${ }^{15}$ Miller A. Punishing Passion: A Comparative Analysis of Adultery Laws in the United States of America and Taiwan and their Effects on Women. Fordham International Law Journal. Vol. 41. Issue 2. P. 433. 
Having committed adultery which she longed so much for, Charity does not enjoy satisfaction but undergoes a serious trial, thus verifying the long-rooted stereotype that "wives and mistresses are often cited as suffering social disadvantages that outweigh those of their male counterparts" $"$.

The primary conflict of the novel is patterned as person vs himself/herself. In the early stages of rising action, the female protagonist perceives her fate:

Charity had had four children because she wanted to. $<\ldots>$ The four of them, taken as a package, represented their mother's first understanding of her place in the world ${ }^{17}$.

The woman's devotion to family and children had to direct her life and the plot, but Charity is a contemporary lady and is interested in feminists' ideas (she reads Spare Rib, by the way). This fact defines her further career:

She'd been working for some years in a university department of sociology. She did this as a necessary change from domesticity, the other half of the successful woman's image ${ }^{18}$.

As it can be seen from the fragment, it is necessary to combine a family and a job for a woman to be successful. The male dominated plot would hardly introduce a conflict where a protagonist should have either to choose or the combine the two issues.

The protagonist revolts and tries to cope with her passion. Charity's protest against a love affair looks exactly feminine-like: right ${ }^{, 19}$.

'I can't possibly be in love with you; you're my boss, it wouldn't be

Charity tries to change her life but she does it in a totally feminine way: "Men and women differ psychologically in the way they act, from the style in which they communicate to the way in which they attempt to influence others" ${ }^{20}$. She is so tightly bound to her relations that her connectedness makes new relations more painful than rewarding.

${ }^{16}$ Miller A. Punishing Passion: A Comparative Analysis of Adultery Laws in the United States of America and Taiwan and their Effects on Women. Fordham International Law Journal. Vol. 41. Issue 2. P. 445.

${ }^{17}$ Oakley A. The Men's Room. London: Flamingo, 1991. P. 4.

18 Oakley A. The Men's Room. London: Flamingo, 1991. P. 5.

${ }^{19}$ Oakley A. The Men's Room. London: Flamingo, 1991. P. 26.

20 Merchant K. How Men and Women Differ: Gender Differences in Communication Styles, Influence Tactics, and Leadership Styles. Senior Thesis. 
Charity's husband hit her across the face ${ }^{21}$ and she felt victimized hence reproducing the deep-rooted stereotype that "In cases of sexual infidelity, male aggression is deemed reasonable because a cheating wife is more shameful than a cheating husband" 22 . She encountered physical and psychological male aggression which arose as her husband's behavioral response to her adultery confession; he committed an act of rude agency protesting against the split marital connectedness.

Concerning connectedness as a marker of feminine discourse structuring, the following fragment may serve an extended example of the concept in question:

For Charity, life was no longer essentially magical; it had been overcome by routine. The children's schools started again on 2 September. In the preceding week, she was busy organising their clothes; washing, cleaning, purchasing and labeling. She took Dan and Harry and Rachel to have their hair cut, and sent Tom down the road with instructions about what to have done to his. Then she took Rachel to the doctor for her booster immunisations. She also began to autumn-clean the house, turning out cupboards and excavating under beds, pulling down curtains and discovering dead plants. No cupboard was safe from her house-wifely skirmishes, and even the goldfish got a new lease of life as she bought an electronic test meter to determine the hardness of the water in which they swam and had their being ${ }^{23}$.

Here, a number of enlisted events happened to the protagonist showing her multiple connections: to her children (Dan, Harry, Rachel, Tom), to her pets (goldfish), to her children's schools (she knew the date when they started and adjusted all the preparations to the date), to her house (she used to clean it every autumn). All the described events constitute a stereotyped feminine "routine" which makes up the protagonist's life. They are absorbing but not rewarding thus may be described as feminine. Charity's overcommitment is directed to the wellbeing of her nearest and dearest but this dedication is unnoticed in all the chores she has to complete. She sacrifices her time to the family welfare

Claremont McKenna College. CMC Senior Theses. 2012. Paper 513. URL: http://scholarship.claremont.edu/cmc_theses/513. P. 16.

${ }^{21}$ Oakley A. The Men's Room. London: Flamingo, 1991. P. 70.

${ }^{22}$ Miller A. Punishing Passion: A Comparative Analysis of Adultery Laws in the United States of America and Taiwan and their Effects on Women. Fordham International Law Journal. Vol. 41. Issue 2. P. 456.

${ }^{23}$ Oakley A. The Men's Room. London: Flamingo, 1991. P. 48. 
and considers it matter-of-fact and proper. This principle fits the longexisted theory ("It is often assumed that women are naturally more altruistic than men, especially their own offspring" 24 ) stating that women are born caregivers ("Our culture continues to define care in feminine terms" ${ }^{, 25}$ ) while men are valued for their brains. Some scholars explain this phenomenon from the ontological positions: "physiological differences between man and women, in particular the effect of male hormones such as testosterone on physical and emotional development, make men more self-assertive, aggressive, dominant and competitive, on average, than women are" ${ }^{26}$. Such reasons have been suggested to explain and even justify inequality between sexes in career promotion and housekeeping.

Charity is opposed in her feminist ideas. Her counterpart is her lover, Mark Carleton. She perceives him a stereotype male when he initiates their love affair. She considers him bold and decisive. Her assuredness disappears when the passion weakens and Mark seeks the other romantic adventure. In her eyes, it is weak and unmanly. She is not alone in her suggestions: men are stereotypically blamed and reproached if they violate prescriptive stereotypes by lacking agency and showing weakness $^{27}$. Uncertainty, indecision, embarrassment govern the male rudeness contaminating their once rational abstract mind.

\section{2. "Matilda's Mistake"}

Can assertiveness and career ambitions negotiate with "natural" feminine traits stereotypically ascribed to anyone born a woman? Does a feminist worldview strengthen or weaken connections in McAdams' interpretation? Does agency prevail connections when it comes to a kind of contest between professionals of different sexes? The novel "Matilda's

${ }^{24}$ Folbre N. (2010). The Milk of Human Kindness. Global Perspectives on Gender and Work: Readings and Interpretations, edit. J. Goodman. Plymouth: Rowman \& Littlefield Publishers, Inc. 2010. P. 148.

${ }^{25}$ Folbre N. (2010). The Milk of Human Kindness. Global Perspectives on Gender and Work: Readings and Interpretations, edit. J. Goodman. Plymouth: Rowman \& Littlefield Publishers, Inc. 2010. P. 154.

${ }^{26}$ Hakim C. Work-Lifestyle Choices in the $21^{\text {st }}$ Century: Preference Theory. New York: Oxford University Press Inc., 2002. P. 221.

27 Moss-Racusin C. A. et al. When men break the gender rules: status incongruity and backlash toward modest men. Psychology of Men and Masculinity 2010. Vol. 11. P. 140-151. 
Mistake" leaves these problems unsolved and encourages the readers to suggest their solution.

This is a rare case in literature when one of the plotlines depicts friendship between women. In "Matilda's Mistake", it is friendship between Willow Cornford, an American married to an Englishman, and Matilda Cressey, a British journalist (Willow and Matilda met when Matilda did an MA in journalism in Minnesota in $1976^{28}$ ). This fact was neither "a static auxiliary" to the central plot development nor a "symptomatic exclusion from it" but rather a "transmission mechanism",29 that facilitated the key conflict to originate and gave reason to some events. Taking into account the stereotyped American attitude towards everything as compared to European rendered by Willow, and Matilda's energetic discposition (Matilda is good at making lists, it's one of the skills that got her this job in the first place ${ }^{30}$ ) and high job position (she is President of the Council for Consumer Affairs), the friendship between the two ladies seems more like business relations. Their meetings are always caused by some pragmatic reason. For example, Willow knew both of Matilda's previous professional experience and her new longawaited appointment (She is pleased to be here, as after fifteen years in journalism it dawned on her that she was unlikely to get a major editorial $j o b^{31}$ ) and decided to ask her friend for a favour requiring her professional skills and present job. She would like Matilda to undertake some investigation of an Alternative Birth Centre - a private clinic offering services of "natural childbirth". The friends made an agreement and the rising action begins.

Desire for love, affection often become motivational themes for "ego development", "psychological well-being", and "personal growth"32 of a female character what triggers plot events succession. In a plot, the concentration of female values and needs falls on a climax which reveals all the secrets or missing points in the story. As far as a stereotyped

${ }^{28}$ Oakley A. Matilda's Mistake. Flamingo, London, 1991. P. 17.

29 Marcus Sh. Between Women: Friendship, Desire, and Marriage in Victorian England. Princeton: Princeton University Press, 2007. P. 3.

${ }^{30}$ Oakley A. Matilda's Mistake. Flamingo, London, 1991. P. 12.

${ }^{31}$ Oakley A. Matilda's Mistake. Flamingo, London, 1991. P. 12.

${ }^{32}$ McAdams D. P. et al. Continuity and change in the life story: A longitudinal study of autobiographical memories in emerging adulthood. Journal of Personality. 2006. Vol. 74. P. 1376. 
woman is assumed to aspire for mutual love resulting in a marriage, A. Oakley introduces this traditional episode into the novel:

"So, what's the discussion you want us to have, Matilda?"

"I want to know what we're doing here together, Steven."

"I would have thought it was obvious," he says.

"I don't want to have just another relationship."

$<\ldots>$

"You want me to stop the world and get off. You want to marry me.”

"Yes." It takes courage for her to say this little word, and then to look at him in the smoky atmosphere and await his response $e^{33}$.

The female protagonist initiates unraveling of relations with her lover. She would like the situation to be clear, their statuses to be distinct and herself to be sure in her future. Matilda demonstrates agency for the sake of connectedness. She starts a conversation, she sets a problem and she wants the problem to be solved. In her favour, of course. She succeeds:

Steven takes Matilda to Lindroos on Aleksanterinkatu and buys her a silver Lapponia ring. The design is pleasingly angular, like ab Alvar Aalto library. Matilda enjoys twisting it round on her finger ${ }^{34}$.

The verbal marker of Matilda's "achievement" is a ring, a symbol of the engaged status. The further succession of events proves Matilda has reached her final goal: she married Steven and got another symbol confirming this status: a ring:

Matilda, in ice-blue silk, slips her Lapponia ring on the same finger as her wedding ring after the ceremony and feels properly married: two rings on the same finger, that's the true sign ${ }^{35}$.

The two rings stand for a marital status and signal such protagonist's traits of character as determination and resoluteness. Finally, she establishes new connectedness but only after activation of agency. She is satisfied with the result what is signified by a word properly. Its dictionary definition ("in a manner that is suitable for the purpose or situation; in a way that is considered right or correct; really, or completely"36) correlates with tradition and stereotype. So, the evident conclusion consists in the fact that no matter what progressive and

${ }^{33}$ Oakley A. Matilda's Mistake. Flamingo, London, 1991. P. 107.

${ }^{34}$ Oakley A. Matilda's Mistake. Flamingo, London, 1991. P. 107.

35 Oakley A. Matilda's Mistake. Flamingo, London, 1991. P. 163.

${ }^{36}$ Macmillan Dictionary. URL: https://www.macmillandictionary.com. 
feminist outlook the protagonist demonstrates, she sticks to the patriarchal tradition of official marriage with all its attributes. Besides, the lexeme proper(ly) is one of the recognizable features of Ann Oakley's literary style (see, for example, her novel "A Proper Holiday" where this word acquires a strong position, i.e. the title, and goes through all the text as a key concept).

Climax isn't always the most important scene in a story. In many stories, it may have no successive falling action or denouement, otherwise the author encourages the reader to predict the continuation or resolution. The same refers the final remarks of the text. When the two key characters of the novel - protagonist (Matilda) and antagonist (Steven) - marry and the story seems to come to its happy end there appears something that excites the reader's interest at the very last page. There is a short dialogue between Matilda and Steven while they are making love:

M.: "Are there things you haven't told me about your past?"

S.: "Of course not. I mean yes, obviously, but nothing important",37.

There are unanswered questions and, accordingly, unresolved problems challenging Matilda in future. But there is no way back:

It's over quickly but it's only a beginning, as ovum and sperm conjoin in the darkness of Matilda's left fallopian tube ${ }^{38}$.

The fragment implies that the final of the previous event (over) switches over to the new one (beginning). Matilda's getting pregnant signals a new event, a new character, a new kind of relations and connectedness. But it is the last sentence of the novel, and the readers have to unwind this imaginative knot themselves.

In terms of McAdams' connectedness, the whole narration presents links, connections, relations etc. Here belong friendship between Matilda and Willow, marital relations between Willow and Antony, family links between Matilda and her parents, Matilda and William's civil marriage, connections between Steven van den Biot and the patients of his clinic - pregnant women, professional relations and later - love affair between Steven and Matilda, Steven's unexpected encounter with his first love Béatrice and sweet memories of youth, the atmosphere between the employees in Matilda's office - all of them women, family relations between Lady Claudia Foxman and her husband, love affair between Lord

${ }^{37}$ Oakley A. Matilda's Mistake. Flamingo, London, 1991. P. 167.

${ }^{38}$ Oakley A. Matilda's Mistake. Flamingo, London, 1991. P. 167. 
Foxman and his mistress, Lady Foxman's romantic feelings and sexual appeal towards Steven and a lot of others. The narrative progression of the novel binds several plotlines where the conflict grounds on some connection with a feminine character being involved. There is not a single description of relations between men only. In fits Judith Butler's theory of identity formation through discoursive practices ${ }^{39}$. Ann Oakley's individual style bears the signals of gender construction, unlike a born sex. This gender identity formation is going on in a fiction text in the form of a plot.

The postmodern frame of the novel's messages and structures asserts the interpretation of identity represented on its pages. The characters' self-perception, self-expression, self-actualisation is verbalized according to the author's selection of lingual instruments. Here, the author's cognitive processes of creating and textualising character images bears the impact of postmodern philosophy where the idea of "self" is only perceptible in relation to "other" $"$. Such correlation and to some extent juxtaposition provides a person with a sense of belonging, connection; affiliation with some community (family, job, friendship etc.) ensures relations, ties and their development. In a text, it results in plot succession.

\section{3. "A Proper Holiday"}

Both men and women benefit from leisure pastime. The plot of "A Proper Holiday" is a picture of English families having their vacation in Turkey. The novel abounds in events and characters. From the first pages, the rhysoma plot structure makes it difficult to identify the number and succession of events.

The analysis of the novel proves that whatever happens in a text, happens for a reason. The cause-and-effect sequence binds all the plot elements together forming a plot line(s). Despite the splitting into multiple story lines, a literary text recreates real life in all its riches and multifacetness. The central theme unites all plot components into a single unit - a text, a cohesive and coherent verbal unit.

${ }^{39}$ Butler J. Gender Trouble: Feminism and the Subversion of Identity. New York: Routledge, 1990. 272 p.; Butler J. Bodies That Matter, on the Discursive Limits of Sex. New York \& London: Routledge, 1993. 256 p.

${ }^{40}$ Hall S. Introduction: Who Needs Identity? Questions of Cultural Identity, edit. Hall S. and du Gay P. London: SAGE, 1996. P. 17. 
The feminine bias of the novel is noticeable from its very beginning: one of the protagonists, Crispin Delancey, having just arrived at the Turkish hotel for a package holiday, observes a woman swimming in the pool and involuntarily compares her with his wife. His represented inner speech expresses his attitude towards them both. The verbal means serve the character descriptions:

She was thirty-ish, he supposed. Her compact body wore a yellow bikini like a second skin. She had light, crinkly hair which sparkled in the sharp mid-morning sunlight, creating altogether the appearance of a svelte, illuminated lemon ${ }^{41}$.

Here, the new acquaintance is depicted by verbal units with positive meaning, for example, compact body, like a second skin, svelte which sound like compliments to a good-looking person. There are several words united by "light" semantics; the word light in hair description; the lexeme sunlight symbolizes the sun - a source of light, energy, life and growth; sparkle and illuminate stand for light and brightness, too; morning stands for sunrise, a new day, new expectations. The meaning of "light" is extended by its tints: yellow (bikini) and lemon. Besides, the suffix - ish denotes "used with many adjectives to make other adjectives meaning slightly or fairly; used with many numbers to make adverbs meaning approximately" ${ }^{\text {. }}$. It is objectified the new acquaintance's description whose age is presented in a diminutive perspective which makes a positive association of youth.

On the contrary, Crispin views his wife in a different way:

"You'll burn if you don't do something about it!" A large tapestry bag arrived by Crispin's right ear accompanied by his fun-loving, fattish, forty-something wife, Dodo ${ }^{43}$.

In contrast to the previous verbal portrait, the suffix -ish is attributed to the general description of Dodo's appearance (fattish). It is not in the wife's favour compared to the previous woman's portrayal but with different verbalization (svelte, compact body). The wife's age is forty-something which is at least ten years more than thirty-ish. What's more, it indicates the husband's ignorance of his wife's exact age. Judging from the events sequence, the first thing Crispin noticed was a bag (large tapestry bag), his wife was just its accompaniment. The only positive

\footnotetext{
${ }^{41}$ Oakley A. A Proper Holiday. Flamingo, London, 1996. P. 1.

${ }^{42}$ Macmillan Dictionary. URL: https://www.macmillandictionary.com.

${ }^{43}$ Oakley A. A Proper Holiday. Flamingo, London, 1996. P. 1.
} 
semantics arises from the attribute fun-loving but it is too weak to combat the pretty stranger.

So, the love triangle is drawn on the first page. It layers the plot making the narrative development easy to predict. Ann Oakley tries to play with the conventions of this tool in her own way making all the three participants of this geometry figure enjoy the vacation differently. She signals to the reader that none of the three is going to suffer having come to such a faraway country to have "a real holiday - one without obligations, without routines, in which one was absolutely free to - well, have a holiday"44. But is this holiday "proper"? The key lexeme in the strong position - the title of the book - implies its denotative meaning ("suitable for a purpose or situation; considered to be morally good; considered to be real or serious; complete in every detail" ${ }^{\prime 4}$ ). By the end of the novel it becomes clear that the attribute "proper" possesses multiple interpretations depending on many circumstances: sex, gender, age, education, social background, profession, nationality, religion, surrounding etc. There are several plotlines concentrating on many characters, and each of them treats "proper" in his/her own way. And behaves respectively.

Taking into account that "narrating is an activity for creating identity as well as for sharing experience" $" 46$, the author forms different identities, both as literary heroes and social constructs (sharing her personal experience of a sociologist and feminist). Ann Oakley portrays the Europeans (the British in particular) who let themselves relax too much violating social norms and human morals. It results in their children's escape, the rampageous fact that even mass media write about. It is a feminine voice, that of a Turkish woman Bilge, that calls on to them with accusations and supplication to come to their senses:

"You're sick and stupid and selfish. You don't deserve your children, no wonder they've run away from you! You're none of you fit to be parents! You should be ashamed of yourselves." There were tears in her eyes, and the red of her hotel uniform ran with sweat. She fell full of heat and feeling and tiredness, and she wanted to go on shouting at them

${ }^{44}$ Oakley A. A Proper Holiday. Flamingo, London, 1996. P. 2.

${ }^{45}$ Macmillan Dictionary. URL: https://www.macmillandictionary.com

46 Daiute C. Narrative Inquiry: A Dynamic Approach. New York: SAGE Publications Inc., 2014. P. 15. 
and hurting them until they all came to their senses and understood what she was trying to tell them ${ }^{47}$.

This desperate shout is supported by another woman - an elderly lady, a former intelligence officer Wilma Blake:

"Mind you," said Wilma, gripping her handbag, "I've got some sympathy with Bilge's point of view."

$<\ldots>$

“Well, look at you all. You're a dissolute lot, aren't you! No wonder your youngsters ran away from you!",48.

These two female characters (Bilge and Wilma) are keepers of traditional morals neglected by the contemporary European societies. They imply the stereotypical feminine function of caretaking and family guarding. Ann Oakley introduces a character of Wilma Blake, an elderly woman, a keeper of traditional moral but not devoid of analytical consideration, and communicates the long-lived values which have survived even under feminist influence and explicate "social harms that befall women over men in adulterous situations" 49 .

The narrative of the novel serves a fragment of the contemporary British reality where representatives of different social strata explicate the way of their functioning in community. The links binding the society into an active and progressing unity serve signs of connectedness realized in the texts. The scope of "immediate constituents" of a narrative is being extended nowadays what does not remain unnoticed by scholars. Take, for example, R. Franzosi's observation stating that "besides social relations, concepts and ideas also stand in relation to each other, with words distributed in conceptual spaces" ${ }^{, 50}$. The moral norms regulating interactions within the depicted community are grounded on socioeconomic dimensions and the conception of morality as the whole nation's guidepost. It proves the suggestion that "socio-economic conditions may affect the function, and perhaps the development, of at least some of the brain areas and structures associated with emotion and

${ }^{47}$ Oakley A. A Proper Holiday. Flamingo, London, 1996. P. 198.

${ }^{48}$ Oakley A. A Proper Holiday. Flamingo, London, 1996. P. 201.

49 Miller A. Punishing Passion: A Comparative Analysis of Adultery Laws in the United States of America and Taiwan and their Effects on Women. Fordham International Law Journal. Vol. 41. Issue 2. P. 447.

50 Franzosi R. Quantitative Narrative Analysis. Thousand Oaks: SAGE Publications, Inc., 2010. P. 52. 
cognition"51. In the novel, these conditions trigger the scope of connections binding the heroes into a system of characters. In contrast to seemingly diverse sets of traits the depicted characters possessed, there are some unifying aspects.

\section{Postmodern Feminine Identity}

The novels under discussion fit the matrix of postmodern writing. At times, the narrative breaks the conventional unity and dashes into unexpected composition shifts. One of them is fragmentation which seems to undermine the text unity and swings the centre. Giving prominence to fragmentation enables Ann Oakley to introduce several plotlines with a protagonist and a message in each. Fragmentation serves a liberation force facilitating the appearance of various if not contrasting characters thus painting the picture of contemporary society free from fixed systems of beliefs, regulations, values, and obligations. This patchwork of literary characters' portraits displays the heterogeneous composition of the British social strata of late $20^{\text {th }}$ century. This corresponds to the rejection of "metanarratives" as found in J.-F. Lyotard's book "The Postmodern Condition: A Report on Knowledge" 52 where the philosopher and literary theorist advocates the idea of multiple "mininarratives". They are more specific and can immediately and precisely depict particular events, people, objects in definite circumstances, within peculiar textual forms etc.

Fragmentation can be observed in all the three texts under analysis but it is most vivid in "A Proper Holiday". At first sight, the fragmented system of characters seems to generate discontinuity and hybridity of the text as a whole. Here, the reader encounters families (the Delanceys, the Dunkerleys, the Uptons, the Hollbeaches, the Shaws) each of which leads its own story and each of them splits into older and younger generations. The connections are intertwined, morals are violated on all age levels, the generation gap comes to the fore exposing the total indifference on the part of the parents and outburst of protesting moods on the part of their teenage children. The "feminine" tint of this fragmentation consists in the

${ }^{51}$ Caravita S. et al. Socio-Economic Factors Related to Moral Reasoning in Childhood and Adolescence: the Missing Link Between Brain and Behaviour. Frontiers in Human Neuroscience. 2012. Vol. 6. P. 3.

${ }^{52}$ Lyotard J.-Fr. The Postmodern Condition: A Report on Knowledge. 1979. Transl. by G. Bennington and B. Massumi. Minneapolis: University of Minnesota, 1984. 135 p. 
fact that there is a female character in each group and this very character influences the plot development.

In postmodern fiction, an identity presentation does not totally depend on the author's ideas directly expressed in a text or proclaimed by characters themselves. It is often implied in details and concealed "between lines". The transparency of a character's identity explication arises from the lingual means depicting his/her lifestyle and consumption. The comforting stability of the character's traits peculiar for, for instance, classical novels is alien to postmodern identity. In Ann Oakley's books, a reader encounters individuals whose identity is embedded in plentiful events constituting the plotline. So, lifestyle choices become vital for text identity framing and narrative development. In the novels in question, this identity is predominantly feminine.

Feminine identity in the novels under analysis can boast of multiplicity of signifiers. If the direct nomination remains unspoken or unexpressed, the effective implication hidden under the denominative folds of the narrative comes out in completely unexpected contexts. Consider, for example, a stereotyped tradition of a wife to take her husband's surname in marriage. Matilda from "Matilda's Mistake" sticks to a different principle:

"It's for Les, Miss Cressey - whoops! Mrs van den Bore-it," she explains later. $<\ldots>$

"It's all right, Margaret," says Matilda, "and I'm not going to change my name. You can stick with the old one. It's easier anyway."

"That's right," says Margaret's sister Lesley that evening. "I approve of that."

"You do, Les?"

"Course I do. She's a professional woman, got a career of her own. Doesn't want to be an appendage of his, does she? ",53.

In the fragment, there are several verbal signals identifying the protagonist as a postmodern type of a feminine identity. The patriarchal nominations like Miss and Mrs seem outdated to a younger colleague what explains her mocking at them. Matilda announces her independence in matrimony by proclaiming her desire to retain her maiden name ( $I$ 'm not going to change my name). The statement is quite unexpected as far as the tradition to acquire a new surname is a deep-rooted one. She is not alone in her creed and is supported by the other feminine character,

${ }^{53}$ Oakley A. Matilda’s Mistake. Flamingo, London, 1991. P. 164. 
Lesley, whose arguments refer exclusively to Matilda's professional value (a professional woman, got a career of her own). According to the text, only professional achievements raise a woman's self-esteem and social rank; otherwise she is bound to be a man's shadow (to be an appendage of his). The protagonist rejects the socially expected connections. If so, the abstract allows to derive some vistas for the further development of events after the narrative is over and the reader closes the book: is the new family's life going to be cloudless and smooth if the wife proclaims selfesteem and self-assurance and her husband is much older than her? will the relations within the family change in case Matilda's career promotion does not progress? Ann Oakley leaves many questions for a curious reader to ponder on yet the only point remains evident: any development or continuation of the plot are feminine-focused, female coloured.

\section{CONCLUSIONS}

Ann Oakley constructs culturally relevant identities. A diverse range of female characters accumulates the postmodern worldview. On the one hand, these are individuals with distinctive traits and established values; on the other - they exemplify lack of autonomy, consumption dependence and reference to the synchronic paradigm in its broad sense.

The "feminine" features of the analysed novels are identified in such aspects: the events that trigger the plot development are brought about by a female character; these events arise from the female character's connectedness (family, job, romance) and are specified by a traditionally accepted feminine approach towards their qualification and evaluation; as far as the three novels bear the signals of postmodern philosophy there are obvious transformations noticeable in female characters representation, in particular, their acquirement of agency features translated through the female activity, resoluteness, determinism implemented in both the narrative flow and lingual units.

\section{SUMMARY}

The paper concerns the significance of identity explication in a plot development. Verbal means of feminine identity representation are considered to be text constructs determining the contents and succession of plot events. The concepts of agency and connectedness serve the matrix within which feminine and masculine characters are treated as bearing stereotyped traits. The study of Ann Oakley's novels "Matilda's Mistake", "The Men's Room", and "A Proper Holiday" proves that the scope of events and the way of their narration are derived from the 
socially and culturally approved system of values, beliefs, morals etc. traditionally attributed to women. The impact of postmodern philosophy upon the analysed texts is traced in the transformations of female characters where the elements of agency and connectedness are often interchanged and intertwined.

\section{REFERENCES}

1. Grysman A. et al. The influence of gender and gender typicality on autobiographical memory across event types and age groups. Memory \& Cognition. 2016. Vol. 44. P. 856-868.

2. Ellemers N. Gender Stereotypes. Annual Review of Psychology. 2018. Vol. 69. P. 275-298.

3. Mansfield E. D., McAdams D. P. Generativity and themes of agency and communion in adult autobiography. Personality and Social Psychology Bulletin. 1996. Vol. 22. P. 721-731.

4. McAdams D. P. et al. Continuity and change in the life story: A longitudinal study of autobiographical memories in emerging adulthood. Journal of Personality. 2006. Vol. 74. P. 1371-1400.

5. Bakan D. The duality of human existence. Boston: Beacon Press, 1966. 242 p.

6. Miller A. Punishing Passion: A Comparative Analysis of Adultery Laws in the United States of America and Taiwan and their Effects on Women. Fordham International Law Journal. Vol. 41. Issue 2. P. 425-471.

7. Constantinople A. Masculinity-femininity: an exception to a famous dictum? Psychological Bulletin. 1973. Vol. 80. P. 389-407.

8. Shapin S. The Science of Subjectivity. Social Studies of Science. 2011. Vol. 42 (2). P. 170-184.

9. Longo M. Fiction and Social Reality. Literature and Narrative as Sociological Resources. London and New York: Routledge, 2016. $176 \mathrm{p}$.

10. Davidson H. M. The literary representation of reality. Res Cogitans. 2018. Vol. 13 (1). P. 111-134.

11. Merchant K. How Men and Women Differ: Gender Differences in Communication Styles, Influence Tactics, and Leadership Styles. Senior Thesis. Claremont McKenna College. CMC Senior Theses. 2012. Paper 513. URL: http://scholarship.claremont.edu/cmc_theses/513.

12. Oakley A. The Men's Room. London: Flamingo, 1991. 312 p.

13. Folbre N. (2010). The Milk of Human Kindness. Global Perspectives on Gender and Work: Readings and Interpretations, edit. 
J. Goodman. Plymouth: Rowman \& Littlefield Publishers, Inc. 2010. P. 147-158.

14. Hakim C. Work-Lifestyle Choices in the $21^{\text {st }}$ Century: Preference Theory. New York: Oxford University Press Inc., 2002. 360 p.

15. Moss-Racusin C. A. et al. When men break the gender rules: status incongruity and backlash toward modest men. Psychology of Men and Masculinity 2010. Vol. 11. P. 140-151.

16. Oakley A. Matilda's Mistake. Flamingo, London, 1991. 167 p.

17. Oakley A. A Proper Holiday. Flamingo, London, 1996. 216 p.

18. Marcus Sh. Between Women : Friendship, Desire, and Marriage in Victorian England. Princeton: Princeton University Press, 2007. 368 p.

19. Macmillan Dictionary. URL: https://www.macmillandictionary.com

20. Daiute C. Narrative Inquiry: A Dynamic Approach. New York: SAGE Publications Inc., 2014. 320 p.

21.Butler J. Gender Trouble: Feminism and the Subversion of Identity. New York: Routledge, 1990. 272 p.

22. Butler J. Bodies That Matter, on the Discursive Limits of Sex. New York \& London: Routledge, 1993. 256 p.

23. Caravita S. et al. Socio-Economic Factors Related to Moral Reasoning in Childhood and Adolescence: the Missing Link Between Brain and Behaviour. Frontiers in Human Neuroscience. 2012. Vol. 6. P. 1-14.

24.Lyotard J.-Fr. The Postmodern Condition: A Report on Knowledge. 1979. Transl. by G. Bennington and B. Massumi. Minneapolis: University of Minnesota, $1984.135 \mathrm{p}$.

25. Hall S. Introduction: Who Needs Identity? Questions of Cultural Identity, edit. Hall S. and du Gay P. London: SAGE, 1996. P. 1-17.

26. Franzosi R. Quantitative Narrative Analysis. Thousand Oaks: SAGE Publications, Inc., 2010. 200 p.

Information about the author: Alla Marchyshyna, Doctor of Philological Sciences, Associate Professor at the Department of the English Language, Kamianets-Podilskiy National Ivan Ohiienko University 50/53, Hrushevskoho ave., Kamianets-Podilskiy, 32300, Ukraine 